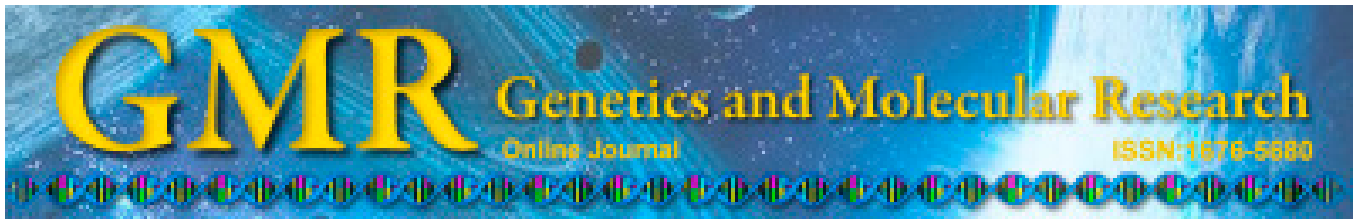

\title{
Repeatability and genotypic correlations of reproductive and productive traits of crossbred beef cattle dams
}

\author{
L.N. Silva ${ }^{1,5}$, E. Gasparino ${ }^{1}$, R.A.A. Torres Júnior ${ }^{2}$, K. Euclides Filho², \\ L.O.C. Silva ${ }^{2}$, M.M. Alencar ${ }^{3}$, M.D. Souza Júnior ${ }^{4}$, J.V.F. Battistelli ${ }^{4}$ and \\ S.C.C. Silva ${ }^{1}$
}

${ }^{1}$ Universidade Estadual de Maringá, Brasil

${ }^{2}$ Embrapa Gado de Corte, Brasil

${ }^{3}$ Embrapa Pecuária Sudeste, Brasil

${ }^{4}$ Universidade Federal do Mato Grosso do Sul, Brasil

${ }^{5}$ Geneplus, Paraná, Brasil

Corresponding author: E. Gasparino

E-mail: egasparino@uem.br

Genet. Mol. Res. 14 (2): 5310-5319 (2015)

Received January 18, 2014

Accepted September 12, 2014

Published May 22, 2015

DOI http://dx.doi.org/10.4238/2015.May.22.1

\begin{abstract}
Beef cattle production requires reproductive efficiency. However, measures of reproductive traits are not usually collected; consequently, correlated traits that could be used as indicators would be useful. We examined associations between measures of reproductive and productive efficiency that could be used as selection indicators. Data from 194 dams of the genetic groups Angus x Nelore, Caracu x Nelore, and Valdostana x Nelore collected over 4
\end{abstract}


years were used. The reproductive traits analyzed were days to heat (DH), calving interval (CI), days to calving (DC), and pregnancy rate (PR). The productive traits were dam weight (DW), body condition score (BCS), calf weight (CW), and weaning rate (WR). The effects on the model were: year, genetic group, reproductive status (RS), age, reproductive rest, and breed of bull (CW and WR). Multivariate analyses were performed, using the Bayesian approach via Gibbs sampling. We conclude that the reproductive measures are ineffective as selection indicators, whereas using dam weight may be a good alternative.

Key words: Bayesian; Beef cattle; Cross breeding; Gibbs sampling; Productive efficiency; Reproductive efficiency

\section{INTRODUCTION}

Beef cattle productivity in the breeding phase is directly related to the number and weight of calves weaned by the dam. The number of calves is related to the dam's reproductive efficiency, which depends on the age at first calving, the calving interval and length of time in the herd. The weaning weight is a trait influenced by the calf's and dam's genotype (Espasandin et al., 2001; Pereira, 2008). The dam's genotype influences the offspring's weight through milk production and maternal care, as well as the direct additive effects passed on to the calf (Alencar, 1989; Albuquerque et al., 1993).

According to Ribeiro et al. (2001), larger cows within one breed or between breeds or crossbreeds generally produce heavier calves at weaning, but they have greater maintenance requirements and usually produce more milk, which increases their nutritional requirements (Kress et al., 1969; Euclides Filho et al., 1984). Stewart and Martin (1983) and Marshall et al. (1984) concluded that there is an optimum weight or size for cows in terms of productive efficiency. The decision regarding the acceptable range of cow size depends on the genetic and environmental resources available, as well as on the maintenance costs of the beef cattle production systems, and on the sale price of discarded cows.

However, to determine the reproductive efficiency of a herd, easier and less expensive forms of measurement can be used, generating relevant indicators. Therefore, studying the correlations between reproductive traits and measures of productive efficiency of cows and calves is important for making decisions on the selection system, when the focus is the efficiency of the offspring herd.

The objective of this study, therefore, was to evaluate the repeatability of measures of productive and reproductive efficiency and their associations, so as to guide decisions regarding their use in the selection process for improved reproductive efficiency.

\section{MATERIAL AND METHODS}

The experiment was conducted at Embrapa Gado de Corte facilities, in Campo Grande, Mato Grosso do Sul. All animals from the herd were maintained on an exclusive grazing regime, receiving unlimited mineral supplements throughout the whole year. 
Field data were used from 194 crossbred dams, from 3 genetic groups - 1/2 Angus $\mathrm{x}$ Nelore, $1 / 2$ Caracu x Nelore and $1 / 2$ Valdostana x Nelore - collected over a 4-year period from the beginning of 2006, covering the season until the first weaning of the 2009 season.

The descriptive statistics from the data are given in Tables 1, 2 and 3.

Table 1. Relative frequency of the animals evaluated by genetic group (GG), management group, and reproductive status (RS) in each year of the breeding season.

\begin{tabular}{llcccc}
\hline & & $2006(\mathrm{~N}=191)$ & $2007(\mathrm{~N}=186)$ & $2008(\mathrm{~N}=162)$ & $2009(\mathrm{~N}=150)$ \\
\hline GG (\%) & AN & 24.61 & 24.19 & 28.4 & 30.00 \\
& CN & 47.12 & 47.85 & 41.98 & 40.67 \\
\multirow{2}{*}{ Management group (\%) } & VN & 28.27 & 27.96 & 29.63 & 29.33 \\
& EC & 66.49 & 73.12 & 26.37 & 29.63 \\
RS (\%) & LC & 33.51 & 82.80 & 67.90 & 38.67 \\
& Calved & 73.82 & 17.20 & 32.10 & 11.33 \\
\hline
\end{tabular}

$\mathrm{AN}=1 / 2$ Angus $\mathrm{x}$ Nelore; $\mathrm{CN}=1 / 2$ Caracu $\times$ Nelore; $\mathrm{VN}=1 / 2$ Valdostana $\times$ Nelore; $\mathrm{EC}=$ early calved dams; $\mathrm{LC}=$ late calved dams.

Table 2. Descriptive statistics for age of dam at start of mating (DA), calving interval at start of mating (CISM), dam weight (DW), calf weight (CW), weaning rate (WR), and body condition score (BCS).

\begin{tabular}{lcccc}
\hline & Observations & Average & Min. & Max. \\
\hline DA (years) & 689 & $7.89 \pm 1.99$ & 2.89 & 10.99 \\
CISM (days) & 523 & $26.57 \pm 28.17$ & -36 & 80 \\
DW (kg) & 373 & $455.0 \pm 66.2$ & 327 & 668 \\
CW (kg) & 379 & $221.1 \pm 27.8$ & 144.2 & 304.5 \\
WR (\%) & 372 & $49 \pm 27$ & 27 & 71 \\
BCS & 372 & $3.38 \pm 0.66$ & 2 & 6 \\
\hline
\end{tabular}

Table 3. Data distribution for days to heat (DH), calving interval (CI), days to calving (DC), and pregnancy rate $(\mathrm{PR})$ distributed in each year.

\begin{tabular}{|c|c|c|c|c|c|}
\hline Year & & 2006 & 2007 & 2008 & 2009 \\
\hline \multirow[t]{2}{*}{ DH } & Total & 127 & 136 & 114 & 119 \\
\hline & Censored & 32 & 57 & 14 & 9 \\
\hline \multirow[t]{2}{*}{ CI } & Total & 141 & 154 & 108 & - \\
\hline & Censored & 30 & 71 & 22 & - \\
\hline \multirow[t]{2}{*}{ DC } & Total & 191 & 186 & 162 & - \\
\hline & Censored & 38 & 78 & 29 & - \\
\hline \multirow[t]{2}{*}{ PR } & Total & 191 & 186 & 162 & 148 \\
\hline & Not pregnant & 37 & 76 & 24 & 21 \\
\hline
\end{tabular}

The breeding seasons began in November of each year and ran until the end of January. The animals were split into two management groups on the basis of the previous calving date, called "Early Calved" (EC), for dams that had calved by October 15 and those that had not calved that year, and "Late Calved" (LC) for dams that had calved after that date. 
The dams from the EC group were subjected to a two-month breeding season, during which they were observed for heat cycle and subjected to artificial insemination, detecting the heat cycle with the use of studs wearing a marking halter, and then subjected to an additional 1-month covering with natural mating, except in the years 2007 and 2009, when they continued to be inseminated until the end of January. The dams from the LC group entered covering with only natural mating, from the start of December until the end of January every year.

Two months after the end of the breeding season, the dams were diagnosed for pregnancy to determine the pregnancy rate.

The reproductive traits analyzed were the interval from the start of the breeding season until the first heat cycle, referred to as days to heat (DH), calving interval (CI) only for dams that had calved on mating, days to calving (DC), comprising the period between the start of the covering season and calving, which show some of the analyzed data that were not actually observed and are considered to be censored data, for which only the lower limit of the trait is known. The result is the pregnancy rate (PR), which is a threshold trait, with the data presented in a binary form (0 or 1$)$.

The values for the censored data were sampled from their respective conditional distributions (truncated normal distribution) in each Gibbs sampling cycle. For all the animals from the same contemporaneous group, truncation was applied to the highest data for the trait; therefore, the predicted value was between the point of truncation and positive infinity. Hence, any animal with censored data would not receive a simulated value less than another non-censored animal within the same contemporaneous group.

The productive traits analyzed were the dam weaning weight (DW), calf weaning weight corrected to 240 days (CW), body condition score at weaning (BCS), and weaning rate (WR), which is the ratio between CW and DW, expressed as a percentage.

The identifiable environmental effects considered in the analyses were the year, management group (except for the interval from the start of the season until the first heat cycle), genetic group, reproductive status (RS) (if the dam was a heifer or feeding offspring), linear effect of the dam's age at the start of the breeding season, linear effect of the interval from calving until the start of the breeding season (reproductive rest) and breed of the bull used only for CW and WR.

For reproductive rest, an 80-day period was considered for heifers and dams that had calved outside the calving season. This means that the solution for the effects of RS allows for direct comparison between the heifers and the dams that have calved with 80 days rest, corresponding to dams that calved at the start of the season.

The cow effects, productive and residual capacity, were considered to be random effects. The inclusion of the random cow effects allows for consideration of the correlation between two measures taken for the same animal, thus avoiding any overestimate of the sample size.

Analyses were conducted in multivariate fashion; one for each reproductive trait simultaneously with all four productive traits. The analyses were performed using a Bayesian approach via Gibbs Sampling, generating a chain of 110,000 and discarding the first 10,000 samples, with a sampling interval of 10 , resulting in a final chain of 10,000 samples.

Thus, with the generated samples, the genotypic and residual (co)variances were obtained and the genotypic and residual correlations calculated, as well as the repeatability values.

After generating the samples with the Gibbs Sampler, the mean, median, standard deviation, and upper and lower limit values were calculated for the posterior credible regions 
with $95 \%$ coverage, correlation between the samples every 1, 10, and 50 samples, effective sample size and estimated Monte Carlo standard error.

\section{RESULTS AND DISCUSSION}

On the basis of the estimated repeatability of the reproductive traits studied, obtained through multi-trait analyses, Table 4 shows that the traits of reproductive efficiency presented low or practically nonexistent repeatability levels. This proves that, even for the experimental herd used with stricter data collection, the correlation between measures in the same animal is low. In other words, animals that show a good result for one of these traits in one specific year will not necessarily show greater measures for that same trait in subsequent years.

\begin{tabular}{|c|c|c|c|c|}
\hline & DC & $\mathrm{CI}$ & DH & PR \\
\hline $\mathrm{DC}$ & $0.0136 \pm 0.0219$ & - & - & - \\
\hline CI & - & $0.0448 \pm 0.0434$ & - & - \\
\hline DH & - & - & $0.0012 \pm 0.0013$ & - \\
\hline PR & - & - & - & $0.1746 \pm 0.0832$ \\
\hline DW & $0.7182 \pm 0.0311$ & $0.7128 \pm 0.0322$ & $0.7054 \pm 0.0327$ & $0.7132 \pm 0.0331$ \\
\hline $\mathrm{BCS}$ & $0.1925 \pm 0.0626$ & $0.1791 \pm 0.0704$ & $0.1796 \pm 0.0598$ & $0.1858 \pm 0.0679$ \\
\hline $\mathrm{CW}$ & $0.1647 \pm 0.0683$ & $0.1786 \pm 0.0676$ & $0.1558 \pm 0.0698$ & $0.1993 \pm 0.0610$ \\
\hline WR & $0.2903 \pm 0.0693$ & $0.3044 \pm 0.0743$ & $0.2926 \pm 0.0636$ & $0.3294 \pm 0.0612$ \\
\hline
\end{tabular}

This low repeatability may have been partially influenced by the use of the effect of reproductive rest in the model.

The DC trait under extensive conditions is easily observed and collected in dams, when calving is routinely recorded. Since DC is defined as the interval between the start date of the covering season of the group (referred to as contemporaneous, or management group) and the next calving, this is feasible on farms with defined breeding seasons, and may be used in either natural or artificial covering systems. The estimated repeatability for DC, as seen in Table 4, was low, as reported in the literature, with an estimated value of $0.0136 \pm 0.0219$, with $95 \%$ credibility interval of 0.00 to 0.0728 . In a Nelore herd, Forni and Albuquerque (2005) found low repeatability values for DC, varying between 0.11 and 0.10. In European breeds, Meyer et al. $(1990,1991)$ and Johnston and Bunter (1996) published values of 0.05 to 0.14 for breeds of bull and 0.18 for Zebu crossbreeds.

$\mathrm{CI}$ is the time between two successive calvings. Therefore, this is only possible for cows in their second successive calving. As this is only based on the period between the two calvings, it may be calculated for a small portion of data, but without information for primiparous cows or cows at the end of their life. Bourdon and Brinks (1983) and Meacham and Notter (1987) concluded that the calving interval does not seem to be a good criterion for improving dams' reproduction in the herd due to a relatively low estimated heritability. Nevertheless, CI is a good alternative for herds that do not have defined breeding seasons and cows that calve all year round. The repeatability found was low, $0.0448 \pm 0.0434$ with $95 \%$ credibility interval of 0.0025 to 0.1505 (Table 4), similar to that found in the literature, in which López de Torre and Brinks (1990) and Yagüe et al. (2009) found repeatability values of 0.14 
and 0.085 , respectively.

DH is a trait that has been studied very little, especially due to the limited collection of such data, bearing in mind that to obtain this trait the herd production system must involve controlled mating or artificial insemination and observation of the heat cycle. However, this also showed low repeatability, similar to the value presented by Yagüe et al. (2009), 0.05 in a Rubia Gallega herd. Likewise, the estimated repeatability for DH was $0.012 \pm 0.0013$, with $95 \%$ credibility interval of 0.0010 to 0.0050 (Table 4 ).

The gestation period is between the 2 measures that use the calving as the observation point of the measurement, which in the literature has shown a repeatability ranging between 0.17 and 0.19 , as reported by Vianna et al. (1964) with the Charolesa breed, Scarpati et al. (1998) with Nelore, Rocha et al. (2005) with Nelore and Hereford x Nelore crossbreed and Yagüe et al. (2009) in a Rubia Gallega herd. In general, the repeatability values cited in the literature are almost always lower than 0.20 , indicating a low correlation between the performances of the dam.

For the PR trait, as shown in Table 4, repeatability was estimated at $0.1746 \pm 0.0832$ with $95 \%$ credibility interval of 0.0416 to 0.3510 . Dearborn et al. (1973) found a repeatability of 0.09 using animals of the Hereford, Angus and Shorthorn breeds and their respective crosses, supporting the results of low repeatability found here.

The same did not occur with the repeatability estimates for the traits of productive efficiency, such as DW, which showed high repeatability, varying from 0.7054 to 0.7182 in the analyses conducted (Table 4); that is, cows that reached weaning with a high or low weight tend to wean in the subsequent seasons with a high or low weight, respectively. This is due to the fact that a significant determining factor of the DW is her size or structure, which defines that large cows weigh more and small cows weigh less. Meyer et al. (1990) found a repeatability of the DW to the yearly mating of 0.42 , which is considered of medium magnitude in a Zebu cross herd, whereas Brinks et al. (1962) found repeatability values of 0.57 and 0.62 for DW in spring and autumn, respectively, representing slightly lower results than those found in this study.

BCS, CW and WR showed low repeatability, thus indicating a low association between the various measures of each trait for the same animal. This can be partly explained by the low heritability and strong influence of environmental variations in different years.

The estimated repeatability for BCS ranged from 0.1791 to 0.1925 , showing the strong influence of random environmental effects and a small variation in the capacity of a dam to repeatedly show a higher or lower body condition at weaning over the course of the years. According to Renquist et al. (2006), the body condition score is related to the PR, CI and weaning weight, which would suggest that the maintenance of an adequate body condition score immediately before, during and after the breeding season may be more important to sustain adequate reproductive performance. As regards the BCS at weaning, animals with a high or low BCS weaned lighter calves compared to animals with a moderate condition. In this study, we used a linear association, which does not consider this behavior.

CW weight showed estimated repeatability values that varied from 0.1558 to 0.1993 , with low influence by genetic and permanent environmental factors, where this may be due to the fact that the cow accounts for only the genetic variance of the offspring. Therefore, it may be maintained that selecting dams based on the weaning weight of just one calf is not a very efficient strategy.

According to Kress et al. (1990), using the WR in a mixed breed herd of animals of 
different sizes to measure productive efficiency is better than using the single measure of the $\mathrm{CW}$ weight, seeing as heavier cows wean heavier calves. However, when compared to the WR, the classification of the animals was altered. Nonetheless, when the average to low repeatability estimated in this study is analyzed, ranging from 0.2903 to 0.3294 in the different analyses, this can be considered a potential measure to be used for selection from a herd of calves.

As in all the analyses, the correlations between the measures of productive efficiency were estimated and are shown in Table 5.

Table 5. Posterior mean and standard deviation for coefficients of genotypic correlation between cow effects for variables days to calving (DC), calving interval (CI), days to heat (DH), pregnancy rate (PR), dam weight (DW), body condition score (BCS), calf weight (CW), and weaning rate (WR).

\begin{tabular}{lcccc}
\hline & CI & DC & DH & PR \\
\hline DW & $0.432 \pm 0.383$ & $0.439 \pm 0.337$ & $0.520 \pm 0.589$ & $-0.344 \pm 0.232$ \\
BCS & $0.282 \pm 0.483$ & $0.273 \pm 0.482$ & $0.077 \pm 0.575$ & $-0.072 \pm 0.382$ \\
CW & $0.799 \pm 0.194^{*}$ & $0.464 \pm 0.627$ & $0.645 \pm 0.479$ & $-0.846 \pm 0.126^{*}$ \\
WR & $-0.085 \pm 0.574$ & $-0.303 \pm 0.450$ & $-0.279 \pm 0.615$ & $-0.110 \pm 0.2965$ \\
DW-BCS & $0.512 \pm 0.505^{*}$ & $0.516 \pm 0.127^{*}$ & $0.476 \pm 0.124^{*}$ & $0.504 \pm 0.134^{*}$ \\
DW-CW & $0.652 \pm 0.205^{*}$ & $0.704 \pm 0.192^{*}$ & $-0.689 \pm 0.199^{*}$ & $0.572 \pm 0.152^{*}$ \\
DW-WR & $-0.880 \pm 0.069^{*}$ & $-0.898 \pm 0.068^{*}$ & $-0.895 \pm 0.069^{*}$ & $-0.858 \pm 0.054^{*}$ \\
DCS-CW & $0.203 \pm 0.383$ & $0.1735 \pm 0.4014$ & $-0.104 \pm 0.382$ & $0.028 \pm 0.337$ \\
BCS-WR & $-0.509 \pm 0.189^{*}$ & $-0.562 \pm 0.185^{*}$ & $-0.545 \pm 0.181^{*}$ & $-0.583 \pm 0.163^{*}$ \\
CW-WR & $-0.254 \pm 0.394$ & $-0.359 \pm 0.382$ & $-0.336 \pm 0.395$ & $-0.094 \pm 0.259$ \\
\hline
\end{tabular}

Correlations followed by asterisk are statistically different from zero based on a 95\% posterior probability interval.

The correlations with DW were average to high; with BCS, they were positive and medium, varying between 0.4757 and 0.5156 , a very similar result compared to Vieira et al. (2005) who found 0.6577 . For CW, they were average to high in the positive sense, varying from 0.5722 to 0.7035 , unlike in Vieira et al. (2005), who observed not only negative but also low values equal to -0.1325 . WR correlations were negative and high, varying between -0.8575 and -0.8979 , showing the impact of the DW on WR.

The correlations of the dam's BCS with CW were positive, but low, varying from 0.0281 to 0.2026 , while with WR, they were of average and negative magnitude, varying between -0.5087 and -0.5834 , which possibly shows the influence of milk production on the weight loss of the dam and weight gain of the calf, resulting in worse body conditions and better weaning rates.

In addition, the correlation between the $\mathrm{CW}$ and the WR was low and negative, varying between -0.3587 and -0.0935 , which is contradictory, seeing as the calf weight is used as the numerator of the formula for WR. This only serves as stronger evidence of the greater importance of CW over WR.

The estimated correlations between CI and productive traits can be seen in Table 5. It can be noted that, in general, the accuracy of these estimates is low. The association with WR was practically nonexistent and low with BCS, as also observed by McManus et al. (2002), with values of -0.01 and 0.21 , respectively, whereas DW showed an intermediate association in contrast to McManus et al. (2002), who found a correlation of -0.25 .

In relation to $\mathrm{CW}$, there was a high, positive and unfavorable association, which was also reported by Mariante and Zancaner (1985), Mercadante et al. (1995), McManus et al. (2002), and Gressler et al. (2005), suggesting that the increased genetic potential for size 
(weight) could be associated with longer CIs, which could be explained by the fact that larger calves can consume more feed, and this increased feeding reduces luteinizing hormone secretion (Escrivão et al., 2009), which is responsible for releasing the egg in the animal's estrous cycle. Another possibility is an intermediate association through the dam's milk production, allowing the calf to grow more and delaying the dam's return to reproduction.

For the DC trait, a low correlation with the BCS and WR was observed, and the latter showed a negative correlation. Although these are of opposite senses, they are favorable, for it is desirable to have a high WR and a short interval between the start of the covering season and calving. This could be explained by the fact that smaller cows have lower maintenance requirements and can therefore satisfy such requirements and more easily present estrus. These smaller cows display a higher WR compared to larger animals.

The productive traits showed a correlation of average magnitude with DC (Table 5), DW (0.4390), BCS (0.2732), CW (0.4640), and weaning weight (-0.3032). DW and CW are both positive, which shows that heavier cows or cows that wean heavier calves have a higher value for the interval between the start of the covering season and subsequent calving. Forni and Albuquerque (2005) estimated 0.07 and Johnston and Bunter (1996) 0.08 for DW, and 0.06 for calf weaning weight. These results can be contrasted with findings by Meyer et al. (1991), who estimated genetic correlations between DC and weight of crossbred cows at different ages, varying from -0.10 to -0.66 .

The residual correlations in Table 6 show that due to environmental effects, in the year in which the cow weans heavier and in better body conditions, it produces a heavier calf, has a lower WR, and tends to have a lower CI and higher PR. Therefore, it follows that in years when cows wean lighter and in worse body conditions, they have a higher WR and also take longer to begin their heat cycle in the previous breeding season.

Table 6. Posterior mean and standard deviation for coefficients of residual correlation between cow effects for variables days to calving (DC), calving interval (CI), days to heat (DH), pregnancy rate (PR), dam weight (DW), body condition score (BCS), calf weight (CW), and weaning rate (WR).

\begin{tabular}{|c|c|c|c|c|}
\hline & $\mathrm{CI}$ & $\mathrm{DC}$ & $\mathrm{DH}$ & PR \\
\hline DW & $-0.580 \pm 0.047^{*}$ & $-0.574 \pm 0.046^{*}$ & $-0.451 \pm 0.060 *$ & $0.591 \pm 0.069 *$ \\
\hline $\mathrm{BCS}$ & $-0.255 \pm 0.062^{*}$ & $-0.250 \pm 0.061^{*}$ & $-0.289 \pm 0.058^{*}$ & $0.232 \pm 0.087 *$ \\
\hline $\mathrm{CW}$ & $-0.030 \pm 0.073$ & $0.003 \pm 0.065$ & $0.089 \pm 0.066$ & $0.191 \pm 0.087 *$ \\
\hline WR & $0.282 \pm 0.064 *$ & $0.304 \pm 0.056^{*}$ & $0.317 \pm 0.058^{*}$ & $-0.174 \pm 0.086^{*}$ \\
\hline DW-BCS & $0.513 \pm 0.046^{*}$ & $0.508 \pm 0.046^{*}$ & $0.519 \pm 0.044^{*}$ & $0.512 \pm 0.047 *$ \\
\hline DW-CW & $-0.151 \pm 0.066^{*}$ & $-0.163 \pm 0.064 *$ & $-0.151 \pm 0.063^{*}$ & $-0.127 \pm 0.064 *$ \\
\hline DW-WR & $-0.607 \pm 0.040^{*}$ & $-0.609 \pm 0.040 *$ & $-0.603 \pm 0.041^{*}$ & $-0.596 \pm 0.041 *$ \\
\hline BCS-CW & $-0.250 \pm 0.066^{*}$ & $-0.242 \pm 0.070^{*}$ & $-0.235 \pm 0.067 *$ & $-0.225 \pm 0.063^{*}$ \\
\hline BCS-WR & $-0.456 \pm 0.057^{*}$ & $-0.443 \pm 0.061^{*}$ & $-0.445 \pm 0.056^{*}$ & $-0.440 \pm 0.055^{*}$ \\
\hline CW-WR & $0.851 \pm 0.019^{*}$ & $0.856 \pm 0.019^{*}$ & $0.855 \pm 0.019 *$ & $0.845 \pm 0.019 *$ \\
\hline
\end{tabular}

Correlations followed by asterisk are statistically different from zero based on a $95 \%$ posterior probability interval.

Table 5 shows the results of the correlations with the PR trait, which were negative with all the other productive traits, meaning that the higher the value of any of these productive traits, the lower the pregnancy rate will be in the herd.

The highest correlation observed and the only one that was significantly different from zero was with the calf weaning weight, which demonstrates that cows that wean heavier calves are less likely to become pregnant. This could be explained (Oliveira, 2006) by the fact that cows with better maternal ability may be better milk producers, which increases their maintenance requirement, and in an environment which does not meet such requirement, reproduc- 
tion may be compromised.

The correlations with DW and WR were of low magnitude, showing that larger cows tend to have a lower PR, and the effect of the WR may have been confused with the DW, in view of the fact that the $\mathrm{CW}$ has a strong effect on PR. The correlation with BCS was practically nonexistent. However, Santos et al. (2009), when calculating the probability of calving in a Nelore herd, found that to obtain a likelihood of calving in the herd of over $80 \%$, the average body condition score should be 5.5 on a scale of 1 to 9 .

The correlations with the DH trait are similar to those with DC and CI, showing a positive correlation of average magnitude with $\mathrm{DW}$ and $\mathrm{CW}$, unlike the results presented by Johnston and Bunter (1995), who found -0.1 and -0.05, respectively, and Meyer et al. (1991), who found -0.05 in relation to dam weight. However, the correlations with WR were low and negative, and with the BCS, it was practically nonexistent (Table 5).

\section{CONCLUSIONS}

The low repeatability values found show that measures of reproductive traits are of little use in isolated observations, as they are subject to heavy influence by temporary environmental effects. High calf and dam weights were shown to indicate reduced reproductive efficiency. This proves that controlling the dam weight may be a good way of controlling reproductive efficiency loss caused by selection as to the calf weight.

\section{REFERENCES}

Albuquerque LG, Eler JP and Costa MRP (1993). Produção de leite e desempenho do bezerro na fase de aleitamento em três raças bovinas de corte. Rev. Bras. Zootec. 22: 745-754.

Alencar MM (1989). Relação entre produção de leite da vaca e desempenho do bezerro nas raças Canchim e Nelore. Rev. Bras. Zootec. 18: 146-156.

Bourdon RM and Brinks JS (1983). Calving date versus calving interval as a reproductive measure in beef cattle. J. Anim. Sci. 57: 1412-1417.

Brinks JS, Clark RT, Kieffer NM and Quesenberry JR (1962). Mature weight in Hereford range cows - Heritability, repeatability and relationship to calf performance. J. Anim. Sci. 21: 501-504.

Dearborn DD, Koch RM, Cundiff LV, Gregory KE, et al. (1973). An analysis of reproductive traits in beef cattle. J. Anim. Sci. 36: 1032-1040.

Escrivão RJ, Webb EC and Garcês AP (2009). Effects of 12 hour calf withdrawal on conception rate and calf performance of Bos indicus cattle under extensive conditions. Trop. Anim. Health Prod. 41: 135-139.

Espasandin AC, Packer IU and Alencar MM (2001). Produção de leite e comportamento de amamentação em cinco sistemas de produção de gado de corte. Rev. Bras. Zootec. 30: 702-708.

Euclides Filho K, Restle J and Olson TA (1984). Medidas de Eficiência na Produção de Terneiros a Partir de Vacas de Tamanho e Habilidade Leiteira Diferentes. In: Reunião Anual da Sociedade Brasileira de Zootecnia Sociedade Brasileira de Zootecnia, Belo Horizonte, 138.

Forni S and Albuquerque LG (2005). Estimates of genetic correlations between days to calving and reproductive and weight traits in Nelore cattle. J. Anim. Sci. 83: 1511-1515.

Gressler MGM, Pereira JCC, Bergmann JAG, Andrade VJ, et al. (2005). Genetic aspects of weaning weight and some reproductive traits in Nellore cattle. Arq. Bras. Med. Vet. Zootec. 57: 533-538.

Johnston DJ and Bunter KL (1996). Days to calving in Angus cattle: Genetic and environmental effects, and covariances with other traits. Livest. Prod. Sci. 45: 13-22.

Kress DD, Hauser ER and Chapman AB (1969). Efficiency of production and cow size in beef cattle. J. Anim. Sci. 29: 373-383.

Kress DD, Doornbos DE and Anderson DC (1990). Performance of crosses among Hereford, Angus and Simmental cattle with different levels of Simmental breeding: V. Calf production, milk production and reproduction of three- to eightyear-old dams. J. Anim. Sci. 68: 1910-1921. 
López de Torre G and Brinks JS (1990). Some alternatives to calving date and interval as measures of fertility in beef cattle. J. Anim. Sci. 68: 2650-2657.

Mariante AS and Zancaner A (1985). Crescimento e Reprodução em Gado Nelore. Visão do Criador e do Pesquisador. 1 ed. dos Criadores, São Paulo.

Marshall TE, Mohler MA and Stewart TS (1984). Relationship of lifetime productivity with mature weight and maturation rate in Red Poll cows. Anim. Prod. 39: 383-387.

McManus C, Saueressig MG, Falcão RA and Serrano G (2002). Componentes reprodutivos e produtivos no rebanho de corte da embrapa cerrados. Rev. Bras. Zootec. 31: 648-657.

Meacham NS and Notter DR (1987). Heritability estimates for calving date in Simmental cattle. J. Anim. Sci. 64: 701-705.

Mercadante MEZ, Lobo RB and Reyes A (1995). Parâmetros genéticos para características de crescimento em zebuínos de carne. Arch. Latinoam. Prod. Anim. 3: 45-89.

Meyer K, Hammond K, Parnell PF and Mackinnon MJ (1990). Estimates of heritability and repeatability for reproductive traits in Australian beef cattle. Livest. Prod. Sci. 25: 15-30.

Meyer K, Hammond K, Mackinnon MJ and Parnell PF (1991). Estimates of covariances between reproduction and growth in Australian beef cattle. J. Anim. Sci. 69: 3533-3543.

Oliveira CAL (2006). Avanços em Melhoramento Genético de Raças de Bovinos de Corte: Melhoramento da Habilidade Materna. Simpósio sobre Desafios e Novas Tecnologias na Bovinocultura de Corte, Brasília,

Pereira JCC (2008). Melhoramento Genético Aplicado à Produção Animal. In: 94 FEPMVZ editora, Belo Horizonte, -62.

Renquist BJ, Oltjen JW, Sainz RD and Calvert CC (2006). Relationship between body condition score and production of multiparous beef cows. Livest. Sci. 104: 147-155.

Ribeiro ELA, Restle J and Rocha MA (2001). Productive efficiency of Angus and Charolais primiparous cows. Rev. Bras. Zootec. 30: 125-132.

Rocha JCMC, Tonhati H, Alencar MM and Lôbo RB (2005). Componentes de variância para o período de gestação em bovinos de corte. Arq. Bras. Med. Vet. Zootec. 57: 784-791.

Santos AS, Abreu UGP, Souza GS and Catto JB (2009). Condição corporal, variação de peso e desempenho reprodutivo de vacas de cria em pastagem nativa do pantanal. Rev. Bras. Zootec. 38: 354-360.

Scarpati MTV, Lôbo RB, Reyes A and Oliveira HN (1998). Modelos Animais Alternativos Para Estimação de Parâmetros Genéticos e Fenotípicos do Período de Gestação na Raça Nelore. In: Reunião Anual Da Sociedade Brasileira De Zootecnia Sociedade Brasileira de Zootecnia, Botucatu, 452-454.

Stewart TS and Martin TG (1983). Optimal mature size of Angus cows for maximum cow productivity. Anim. Prod. 37 : 179-182.

Vianna AT, Alba J, Paez G and Magofke C (1964). Forma en que se hereda el peso al nacer y la longitud de gestación en el ganado Charoles. Turrialba 14: 120-127.

Vieira A, Lobato JFP, Torres Junior RAA and Cezar IM (2005). Fatores Determinantes do Desempenho Reprodutivo de Vacas Nelore na Região dos Cerrados do Brasil Central. Rev. Bras. Zootec. 34: 2408-2416.

Yagüe G, Goyache F, Becerra J, Moreno C, et al. (2009). Bayesian estimates of genetic parameters for pre-conception traits, gestation length and calving interval in beef cattle. Anim. Reprod. Sci. 114: 72-80. 